\title{
Laboreal
}

Volume 13 №2 | 2017

Varia

\section{Violência e trabalho}

Violencia y trabajo

Violence et travail

Violence and work

\section{Laerte Idal Sznelwar}

\section{OpenEdition}

\section{Journals}

\section{Edição electrónica}

URL: http://journals.openedition.org/laboreal/398

DOI: 10.4000/laboreal.398

ISSN: 1646-5237

\section{Editora}

Universidade do Porto

\section{Refêrencia eletrónica}

Laerte Idal Sznelwar, «Violência e trabalho », Laboreal [Online], Volume 13 №2 | 2017, posto online no dia 01 dezembro 2017, consultado o 14 setembro 2020. URL : http://journals.openedition.org/ laboreal/398

Este documento foi criado de forma automática no dia 14 setembro 2020.

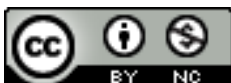

Laboreal está licenciado com uma Licença Creative Commons - Atribuição-NãoComercial 4.0 Internacional. 


\title{
Violência e trabalho
}

\author{
Violencia y trabajo \\ Violence et travail \\ Violence and work \\ Laerte Idal Sznelwar
}

\section{NOTA DO EDITOR}

http://dx.doi.org/10.15667/laborealxiii0217ls

1 Tratar da questão da violência no trabalho é um grande desafio, uma vez que há uma série de discussões e polêmicas sobre como definir o que é violência e como distingui-la de outros tipos de fenômeno relacionados às relações humanas. No caso específico de muitas pessoas que trabalham, diferentes modos de relacionamento modulados pela organização do trabalho são, de alguma maneira, fonte de sofrimento patogênico. Todavia não podemos classificar todos os tipos de constrangimento, como violência, uma vez que há um grande risco de banalização e da perda do poder de caracterização e compreensão das suas origens e como se dissemina nos ambientes de trabalho. Caracterizar o que entendemos por violência em um determinado contexto é importante para que se possa efetivamente responsabilizar aqueles que, de alguma maneira, agem violentamente.

2 As definições mais costumeiras distinguem danos físicos, psíquicos e sociais para caracterizarem um ato violento. Todavia, apesar de podermos distingui-los, não há como separar, pois a experiência vivida por aquele que sofre do uso da coerção imputada por outrem é vivenciada em todos esses aspectos. Isto porque, não há como separar dano físico e moral, uma vez que não podemos considerar que haja uma separação entre corpo e a psique, os dois são sempre envolvidos quando se trata do resultado de algum ato violento. Todavia, a ação daquele (s) que tem como intenção de atingir o outro e de lhe causar danos, pode estar mais direcionada, em um primeiro momento, para o corpo ou para a psique. 
3 A violência é sempre relacional, fruto da ação de alguém ou, mesmo de várias pessoas, dirigida a outrem. No caso das situações de trabalho podemos considerar que há todo um espectro de ações que podem ser consideradas como violentas, das mais explícitas até as mais sutis, pouco perceptíveis para aqueles que não são diretamente envolvidos.

Dentre as mais diversas profissões, há aquelas onde a violência está sempre presente, isto porque são atividades humanas envolvidas com, por exemplo, a segurança pública. Nesses casos, os profissionais agem para prevenir ou conter atos violentos de outros, sendo autorizados pelo Estado a usar a força para que os objetivos de segurança sejam atingidos. Mesmo havendo algum tipo de preparação para que esses profissionais tenham habilidades para agir frente a situações onde o outro é fonte de perigo; há muitas ações desses profissionais, derivam em direção à violência, sendo eles também agentes da passagem ao ato. Tudo isso apesar do fato que o seu papel seja principalmente voltado para apaziguar as relações sociais. Quais são as consequências para esses trabalhadores e para aqueles que sofrem atos violentos, tanto em termos físicos como morais? Isto porque ninguém está isento e protegido. Diferentes trabalhos mostram a importância do sofrimento patogênico nessas categorias profissionais, incluindo casos de suicídio.

5 Em outras situações, profissionais que atuam em situações de relação de serviço, se confrontam com atos violentos de outros sujeitos, sejam eles impetrados por cidadãos, usuários, clientes com os quais se relacionam em suas atividades cotidianas. Nesses casos, apesar de não haver, algo diretamente relacionado com a violência em si, há situações de conflito de interesse que podem desencadeá-la. Infelizmente não são raras as situações em que agentes, em serviços públicos e privados, vivenciam situações de franca agressão seja através da fala ou de agressões físicas. A experiência de ser agredido redunda, muitas vezes, em grandes dificuldades com relação ao trabalho. A perda de sentido daquilo que fazem, o medo de se encontrar novamente em situação similar podem redundar no desenvolvimento de sofrimento patogênico que se expressam em distúrbios; como síndromes pós-traumáticas, depressão, entre outras.

6 Esta questão relacional ligada ao contato com o público, geralmente é desconsiderada pelas modalidades de organização do trabalho e pelos dispositivos de avaliação de desempenho. Os problemas resultantes estão fortemente ligados aos processos de individualização, onde podem os colegas competirem por algum tipo de benefício, financeiro ou de outra ordem, como uma promoção ou a obtenção de recursos. Todavia, há muitas situações onde o trabalhador, pouco pode fazer pela outra pessoa; nesses casos, o risco de ser agredido aumenta, ainda mais estando ele sozinho. Ressalte-se ainda que há casos em que mesmo sabendo que a pessoa em face tem razão, ele não tem autonomia para agir em prol de uma solução mais adequada. Este cenário, que pode ser desolador, está na origem de muitos conflitos e da explosão de episódios de violência por parte de quem está em contato com o trabalhador.

7 Em ambientes onde há uma grande competitividade entre colegas e o que mais importa é atingir metas anteriormente definidas pela hierarquia, há um forte risco de se encontrarem isolados e fragilizados frente a situações de assédio. Por um lado, estariam sujeitos a pressões da hierarquia, pressões essas que extrapolam o que seria legítimo com relação a trabalhar bem e de modo eficiente e; por outro lado, não podem contar com a solidariedade de colegas, uma vez que estão todos competindo entre si. Trata-se de uma violência mais sutil, menos evidente, mas que também pode ser considerada como tal, sobretudo por se tratar de um tipo de ação que tem como finalidade, causar 
dano àquela pessoa. A inexistência de espaços de troca de experiência e de deliberação coletiva são um terreno propício para a construção de cenários de produção onde a violência emerge; são cenários para que se trate o outro como coisa, em processos de reificação, onde reforçam diferentes maneiras de clivagem nas relações sociais e com relação à economia psíquica de cada um.

8 A relação entre violência e desemprego também é importante. Apesar de não podermos fazer uma relação direta, na base de um posicionamento do tipo causa e efeito, o fato que se perder o sentido da utilidade social e a própria possibilidade de reforço da identidade, coloca o sujeito numa situação de fragilidade, onde a violência tanto dos outros com relação a si como a sua com relação aos outros, pode emergir. Isto tende a acontecer com mais frequência, uma vez que, o papel do trabalho, enquanto potencial sublimatório, está perdido. $\mathrm{O}$ desemprego, fato muito frequente em nossos sistemas econômicos é, potencialmente, um fator gerador ou que potencializa a violência.

Violência contra si mesmo também precisa ser considerada, uma vez que processos de autoagressão se tornaram mais conhecidos no espaço público devido a casos de suicídio, infelizmente com incidência crescente no mundo do trabalho. Trata-se de uma discussão ainda mais complicada, uma vez que ao tratarmos da violência de outrem, podemos caracterizar como um ato dirigido e intencional, fruto de algum tipo de estratégia de poder, de dominação. No caso de processos contra si, há que se considerar a importância de mecanismos inconscientes que, no âmbito da economia psíquica, estão direcionados contra o próprio sujeito. Cabe ainda considerar que, mesmo no caso de atos de violência contra outrem, não se trata apenas de ações conscientes e pensadas como uma estratégia de dominação, uma vez que os modos de relação social modulados por opções organizacionais reforçam os mecanismos inconscientes da clivagem. A passagem ao ato, à violência tem a ver com a irrupção daquilo que ficou, de alguma, maneira, relegado, escondido.

Ressalte-se que este pequeno texto deve ser considerado apenas como uma introdução ao tema, bastante incompleto. Há uma vasta literatura assim como grupos de estudo e promotores de políticas públicas que tratam dessa questão. Um importante trabalho de reflexão foi publicado em livro coordenado por Christophe Dejours (2007), desenvolvido em cooperação com outros autores.

\section{BIBLIOGRAFIA}

Dejours, C. (sous la direction de) (2007). Conjurer la violence : travail, violence et santé. Paris : Payot et Rivages.

\section{ÍNDICE}

Temas: O Dicionário 


\section{AUTOR}

\section{LAERTE IDAL SZNELWAR}

Departamento de Engenharia de Produção Escola Politécnica

Universidade de São Paulo

Av. Professor Almeida Prado, trav. 2 no 128 - CEP 05508-900, Cidade Universitária, São Paulo - SP Brasil

aertesz@usp.br 